Journal of Strategic Security

Volume 9

Number 1 Volume 9, No. 1, Special Issue

Spring 2016: Designing Danger: Complex

Article 13

Engineering by Violent Non-State Actors

\title{
Relentless Strike: The Secret History of Joint Special Operations \\ Command. By Sean Naylor. New York: St. Martin's Press, 2015
}

Martin S. Catino Ph.D.,

American Military University

Follow this and additional works at: https://digitalcommons.usf.edu/jss

pp. $142-143$

\section{Recommended Citation}

Catino, Martin S. Ph.D.,. "Relentless Strike: The Secret History of Joint Special Operations Command. By Sean Naylor. New York: St. Martin's Press, 2015." Journal of Strategic Security 9, no. 1 (2016) : 142-143.

DOI: http://dx.doi.org/10.5038/1944-0472.9.1.1518

Available at: https://digitalcommons.usf.edu/jss/vol9/iss1/13

This Book Review is brought to you for free and open access by the Open Access Journals at Digital Commons @ University of South Florida. It has been accepted for inclusion in Journal of Strategic Security by an authorized editor of Digital Commons @ University of South Florida. For more information, please contact digitalcommons@usf.edu. 


\section{Relentless Strike: The Secret History of Joint Special}

Operations Command. By Sean Naylor. New York: St. Martin's Press, 2015 


\section{Relentless Strike: The Secret History of Joint Special Operations Command. By Sean Naylor. New York: St. Martin's Press, 2015. ISBN 978-1-01454-2. Bibliography. Notes. Maps. Glossary. Index. Pp. xviii, 540. \$29.99.}

From the deserts of Syria and Iraq, to the shadowy nights of Abbottabad, Pakistan and the dusty tribal realms of Yemen among other places, United States Special Operations Forces (SOF) have struck down America's deadliest enemies while distinguishing SOF as the most potent military force on the planet. Osama bin Laden and Anwar al-Awlaki are just a couple of wellknown examples who met their fate at the hands of SOF. Entering the secret world of these "quiet professionals" is no small matter, much less writing a detailed, insightful, and accurate history of their operations and the component command that has guided their readiness, tactics, and deployments since 1980. Nevertheless, Sean Naylor has achieved this very feat through not only chronicling the growth of Joint Special Operations Command (JSOC) from its limited mission sets to its current and central role as a strategic player, but also capturing the personalities, missions, and events that have shaped this extraordinary arm of U.S. military power.

Naylor's current position as senior staff writer of Foreign Policy covering counterterrorism and intelligence issues contributes to the book's understanding of these areas, but his twenty-three years as a writer for Army Times is more significant concerning the book's quality. The author specialized in reporting on SOF as well as the critical aspects of military readiness, operations, force modernization, and leadership. Also, Naylor was among a relatively few journalists who had embedded with US forces in the early days of Operation Enduring Freedom-Afghanistan and thus developed relationships and perspectives that contributed to the lively prose and understanding of key missions.

Consequently, Relentless Strike is filled with insights that can be overlooked easily by the reader for the lively imagery and intense action of the book. JSOC's decision-making, planning, tactics, missions, and execution of operations are laid bare causing more than a few members of the SOF community to question the purpose and risks of such a study. Not surprisingly, USSOCOM (United States Special Operations Command) reminded its personnel after the release of the book that they are bound by the protocols that address the handling of sensitive information. But the same enemy who may learn more about the tactics of SOF will also learn more about its resolve, courage, and capabilities for finding, penetrating, degrading, 
and destroying hostile actors and their organizations and missions.

Furthermore, Relentless Strike excels at accurately portraying the interplay of personalities, leadership styles, organizational and unit characteristics, and divergent mission priorities. The case of General Stanley McChrystal serves as an example. Naylor depicted McChrystal as an outsider to JSOC leadership at Ft. Bragg, North Carolina, but aided by the increasing reliance of Delta Forces on Ranger elements from the general's former regiment. His plan for increasing the role of SOF in major operations in Iraq ("surge"), high operational tempo, focus on eliminating foreign fighters-and not former regime elements-placed him at odds with personnel in his own organization as well as U.S. Army General George Casey, commanding conventional military forces in Iraq. McChrystal's energetic leadership style that contrasted with his predecessor, his focus on the elimination of Al Qaeda's middle level leadership and structures, and the killing of Abu Musab alZarqawi further distinguished the general, Naylor notes.

Perhaps most importantly, Relentless Strike provides valuable information on previously underreported operations. The detail on Syria is a notable example. Naylor addresses the major operations of SOF in Syria, pursuing Saddam Hussein, his possible movement of Weapons of Mass Destruction (WMD) materials, and foreign fighter networks transiting the region through that country. No doubt, the "web of imams, financiers, ideologues, facilitators, and fighters" (269) had attracted the attention of JSOC, which prioritized the mission to interdict these "rat lines" that were destabilizing Iraq. Adding to the clarity provided by these narratives on Syria are equally vivid accounts of Operation Neptune Spear, and Operation Lightning Dawn; the operations that targeted Osama bin Laden and the rescue of Captain Richard Phillips from Somali pirates, respectively. Naylor's contribution to the history of these missions is one of providing historical accuracy rather than sensationalized media accounts.

Relentless Strike: The Secret History of Joint Special Operations Command by Sean Naylor has contributed significantly to the history and understanding of JSOC and Special Operations Forces. Military historians, military studies experts, and a general readership seeking more insights into the most potent fighting force on earth will find this book invaluable for its information, clarity, and detail.

Martin Scott Catino, Ph.D., American Military University 